\title{
Peningkatan Keterampilan Proses Sains Siswa melalui Context Based Learning
}

\author{
Adam Malik ${ }^{\text {a) }}$, Endah Kurnia Y, Siti Robiatus S \\ Prodi Pendidikan Fisika, FTK UIN Sunan Gunung Djati, Jl. A.H. Nasution No 105, Bandung \\ Email: a)adammalik@uinsgd.ac.id
}

\begin{abstract}
Rigid object equilibrium is a material that needs well rule and process aplication viewed from tranlation and rotation concept. This phenomenon related to material aplication was much found in daily life. This material instruction requires the development of Saintific Process Skills (SPS). Based on the observation result in MAN Cisewu, this material was considered difficult for the student. The teacher taught the material with mathematical formulas wihthout practicing the saintific process. One of the efforts to solve the problem by using model Context Based Learning (CBL). CBL connects content and contex. It helps the students to be more creative informing concept individually and improves the saintific process skills. Through one grup pretest-posttest design in pre experiment method, the research aims finding out the use of CBL model by using observation sheet and improving students' saintific process skills measured by multiple choices. The result shows percentage of teacher activity $87,00 \%$ (good) and students $85,22 \%$ (good). The improvement of students' saintific process skills showed $0,58 \%$ (medium) for $\mathrm{N}$-gain means. The indicator of saintific process skills communicate of the lowest N-Gain $(0,06)$ and the highest N-Gain $(0,73)$ apperead on the indicator of interpretation. Hyphothetical test showed by Wilcoxon match pairs, it is found that $Z_{\text {count }}$ $(5,70)>Z_{\text {table }}(1,69)$. It can be concluded that Context Based Learning can improve saintific process skills of students in material rigid object equilibrium.
\end{abstract}

Keywords: CBL, SPS, rigid object equilibrium

\begin{abstract}
Abstrak
Keseimbangan benda tegar merupakan materi yang memerlukan penerapan aturan dan proses baik ditinjau dari konsep tranlasi maupun rotasi. Fenomena dan aplikasi yang berkaitan dengan materi ini banyak ditemukan dalam kehidupan sehari-hari Pembelajaran materi ini menuntut pengembangan Keterampilan Proses Sains (KPS). Berdasarkan hasil observasi di MAN Cisewu materi ini dianggap sulit bagi siswa. Guru mengajarkannya dengan cara perumusan matematis dan kurang melatihkan proses sains. Salah satu upaya untuk mengatasinya dengan menerapkan model Context Based Learning (CBL). CBL menghubungkan konten dengan konteks, dapat membantu siswa kreatif dalam membentuk sebuah konsep secara mandiri dan meningkatkan keterampilan proses sains. Melalui metode pre-eksperimen dengan desain onegroup pretest-posttest, penelitian ini bertujuan untuk mengetahui keterlaksanaan model CBL yang diamati dengan menggunakan lembar observasi dan peningkatan keterampilan proses sains siswa yang diukur menggunakan soal pilihan ganda. Hasil penelitian menunjukkan persentase keterlaksanaan aktivitas guru $87,00 \%$ (baik) dan siswa 85,22\% (baik). Peningkatan keterampilan proses sains siswa diperoleh rata-rata nilai $N$-Gain sebesar 0,58 (sedang).
\end{abstract}


Indikator keterampilan proses sains mengkomunikasikan memperoleh $\mathrm{N}$-Gain terendah $(0,06)$ dan $N$-Gain tertinggi $(0,73)$ pada indikator menafsirkan. Hasil uji hipotesis menggunakan uji Wilcoxon match pairs diperoleh $Z_{\text {hitung }}(5,70)>Z_{\text {tabel }}(1,69)$. Dengan demikian dapat disimpulkan bahwa model Context Based Learning dapat meningkatkan keterampilan proses sains siswa pada materi keseimbangan benda tegar.

Kata-kata kunci: CBL, KPS, keseimbangan benda tegar

\section{PENDAHULUAN}

Pengajaran fisika di SMA dimaksudkan sebagai sarana untuk membimbing dan melatih para siswa agar dapat menguasai pengetahuan, konsep dan prinsip fisika, memiliki kecakapan dan sikap ilmiah, memiliki keterampilan proses sains serta keterampilan berpikir kritis dan kreatif untuk memecahkan masalah dalam kehidupan sehari-hari. Hal tersebut sejalan dengan Permendiknas Nomor 22 Tahun 2006 tentang Standar Isi yang menyebutkan bahwa salah satu tujuan mata pelajaran fisika di SMA adalah agar peserta didik dapat mengembangkan kemampuan bernalar dalam berpikir analisis induktif dan deduktif dengan menggunakan konsep dan prinsip fisika untuk menjelaskan berbagai peristiwa alam dan menyelesaikan masalah baik secara kualitatif maupun kuantitatif.

Keterampilan proses sains (KPS) merupakan seperangkat keterampilan yang melibatkan keterampilan intelektual, manual dan sosial yang digunakan untuk membangun pemahaman terhadap suatu konsep/gagasan/pengetahuan dan meyakinkan/menyempurnakan pemahaman yang sudah terbentuk (Rustaman et al., 2004). Menurut Sagala (2009: 74) keterampilan proses didapatkan dengan melakukan suatu pendekatan pengajaran yang memberi kesempatan kepada siswa untuk ikut mengahayati proses penemuan atau penyusunan suatu konsep. Kegiatan pembelajaran harus berorientasikan keterampilan proses, sebagaimana yang telah dikemukakan oleh Semiawan (1987: 5) dengan mengembangkan keterampilan memproseskan perolehan, anak akan mampu menemukan dan mengembangkan sendiri fakta dan konsep serta menumbuhkan dan mengembangkan sikap dan nilai yang dituntut. Dengan demikian, berbagai keterampilan tersebut menjadi stimulus untuk menemukan dan mengembangkan fakta dan konsep serta menumbuhkan dan mengembangkan sikap dan nilai.

Berdasarkan studi pendahuluan melalui wawancara dengan guru fisika kelas X1 MAN Cisewu menyatakan bahwa siswa menganggap mata pelajaran fisika sulit dan membosankan sehingga siswa kurang terlibat aktif dalam kegiatan pembelajaran di kelas, siswa pun masih belum dapat mengaitkan dan mengaplikasikan materi yang dipelajari di kelas dengan kehidupan sehari-hari. Selain itu, kemampuan pengamatan masih kurang dilatihkan karena pada tahun ajaran 2014/2015 belum pernah dilaksanakan kegiatan praktikum terkait materi yang dipelajari.

Hasil observasi pembelajaran fisika di kelas X1 MAN Cisewu menunjukkan kegiatan pembelajaran masih berpusat pada guru, siswa hanya mendengarkan penjelasan dari guru, membuat catatan, dan memecahkan masalah melalui proses menghafal dan menerapkan rumus matematis. Hal tersebut membuat siswa terlihat tidak antusias dan kurang aktif mengikuti pembelajaran.

Salah satu cara untuk mengatasi permasalahan tersebut adalah dengan menerapkan model Context Based Learning (CBL). Menurut Trimmer W. et al. (2013: 6) CBL merupakan proses mengajar menggunakan pendekatan kelompok dimana proses belajar dilakukan dalam bentuk bekerja sama untuk menemukan konsep dan membawa siswa fokus terhadap peristiwa atau masalah yang ada. Model ini memiliki empat langkah yaitu: 1) langkah questions; 2) langkah answers; 3) langkah selecting informations; 4) langkah applications. CBL adalah sebuah metode pedagogis dalam berbagai cara yang berpusat pada pengetahuan konteks dunia nyata siswa untuk membentuk suatu konsep/gagasan/pengetahuan (Edward, 2012: 1). Berdasarkan kelebihan dari CBL tersebut diharapkan dapat meningkatkan Keterampilan Proses Sains (KPS) siswa. KPS siswa yang dikembangkan dalam penelitian ini mengacu pada pendapat yang dikemukakan Rustaman et al. (2004). Adapun indikator KPS yang dilatih dan dikembangkan meliputi: kemampuan mengamati, merencanakan percobaan, membuat hipotesis, menerapkan konsep, menggunakan alat dan bahan, mengkomunikasikan, mengajukan pertanyaan, menafsirkan, mengklasifikasikan, dan memprediksi.

Hasil penelitian Muthi (2014: 1) menunjukkan bahwa CBL dapat meningkatkan keterampilan proses sains siswa pada materi garam terhidrolisis. Kemudian hasil penelitian Wiana (2014: 1) menunjukkan bahwa CBL dapat meningkatkan keterampilan generik sains siswa pada materi koloid. 
Hal ini selaras dengan hasil penelitian Seery (2014: 5) yang menunjukkan CBL dapat memotivasi siswa untuk mempunyai pengetahuan awal dan meningkatkan literasi sains siswa. Selain itu, CBL dapat meningkatkan hasil kognitif, afektif dan psikomotorik siswa dengan mengembangkan instrumen untuk data kuantitatif dan kualitatif (Putter-Smith, 2013: 457). Hal ini memperkuat penelitian sebelumnya oleh Tural (2013: 1) CBL dapat meningkatkan prestasi dan minat siswa terhadap pembelajaran fisika dan hasil penelitian Trimmer W et al. (2013: 6) yang menyimpulkan CBL dapat membantu siswa dalam membangun kemampuan, kreativitas dan analisis kritis.

Hasil penelitian lainnya terkait model CBL dikemukakan oleh King (2012: 41) bahwa CBL dapat meningkatkan pemahaman dan motivasi siswa dalam pembelajaran kimia. Selain itu, Arroio (2010: 139) menyatakan bahwa CBL dapat meningkatkan pemahaman konsep siswa dan Ilka and Luecken (2010: 12) juga menyatakan bahwa CBL dapat memberikan efek positif siswa pada kegiatan pembelajaran dan belajar berkelompok sangat diperlukan dalam kegiatan pembelajaran ini.

\section{METODE}

Metode penelitian yang digunakan adalah metode quasi eksperimen dengan desain eksperimen pretest posttest satu kelompok (Fraenkel and Wallen, 2007). Penelitian ini di laksanakan di MAN Cisewu pada semester genap tahun ajaran 2014/2015. Seluruh kelas XI MIA sebanyak tiga kelas dijadikan sebagai populasi. Teknik pengambilan sampel yang digunakan simple random sampling, dimana sampel yang terpilih adalah kelas XI MIA 1.

Instrumen penelitian yang digunakan terdiri dari: (1) Lembar observasi digunakan untuk mendapatkan data keterlaksanaan model CBL pada materi keseimbangan benda tegar. Observer memberi tanda cheklis $(\sqrt{ })$ pada kolom "Ya" atau menceklis $(\sqrt{ })$ kolom "Tidak" dan komentar mengenai keterlaksanaan pada setiap kegiatan yang dilakukan guru dan siswa selama pembelajaran. Aktivitas guru dan siswa pada setiap pertemuan (pertama sampai ketiga) sebanyak 24 kegiatan; (2) Tes Keterampilan Proses Sains (KPS) dilaksanakan untuk mengetahui seberapa signifikan peningkatan KPS siswa pada materi keseimbangan benda tegar. Tes ini diujikan diawal dan diakhir penelitian dalam bentuk pilihan ganda dengan jumlah soal sebanyak sepuluh butir. Indikatorindikator KPS yang dikembangkan meliputi: kemampuan mengamati, merencanakan percobaan, membuat hipotesis, menerapkan konsep, menggunakan alat dan bahan, mengkomunikasikan, mengajukan pertanyaan, menafsirkan, mengklasifikasikan, dan memprediksi. Pedoman penskoran untuk tes keterampilan proses sains adalah skor 0 untuk jawaban salah dan 1 untuk jawaban benar. Untuk menguji kesahihan tes dilakukan uji coba instrumen. Data hasil uji coba instrumen dianalisis dengan menggunakan software program Anates 4.0.9. Peningkatan N-gain KPS menggunakan rumus Hake (Cheng et al., 2004). Uji hipotesis dilakukan dengan menggunakan teknik uji statistik yang sesuai dengan distribusi data yang diperoleh. Pengolahan data dengan menggunakan program SPSS for windows versi 19.0 dimana sebelum uji hipotesis, terlebih dahulu dilakukan uji normalitas.

\section{HASIL DAN PEMBAHASAN}

\section{Hasil}

\section{Keterlaksanaan Model CBL}

Berdasarkan data observasi keterlaksanaan aktivitas guru dan aktivitas siswa pada setiap langkah model CBL di setiap pertemuan ditunjukkan pada TABEL 1 berikut.

Berdasarkan TABEL 1 terjadi peningkatan keterlaksanaan baik pada aktivitas guru maupun siswa pada setiap langkah model CBL di setiap pertemuannya. Peningkatan terbesar aktivitas guru dari pertemuan pertama sampai ketiga terdapat pada langkah aplications $(11,11 \%)$ dan terendah pada langkah question (2,23\%). Langkah question dan answer (22,22\%) mengalami peningkatan terbesar pada aktivitas siswa dari pertemuan pertama sampai ketiga dan terendah pada langkah aplication $(12,96)$. Rata-rata keterlaksanaan aktivitas guru terendah pada langkah aplications sebesar 83,95\% termasuk ke dalam interpretasi baik sedangkan tertinggi pada langkah selecting informations sebesar $85,93 \%$ termasuk ke dalam interpretasi baik. Langkah aplications sebesar 79,02\% termasuk ke dalam 
interpretasi baik menunjukkan keterlaksanaan aktivitas siswa terendah sedangkan tertinggi terjadi pada langkah answers sebesar $88,89 \%$ termasuk ke dalam interpretasi baik.

TABEL 1. Keterlaksanaan Aktivitas Guru dan Aktivitas Siswa pada Setiap Langkah Model CBL.

\begin{tabular}{ccccccccccc}
\hline $\begin{array}{c}\text { Langkah } \\
\text { model CBL }\end{array}$ & \multicolumn{2}{c}{ Pertemuan ke-1 } & \multicolumn{2}{c}{ Pertemuan ke-2 } & \multicolumn{2}{c}{ Pertemuan ke-3 } & \multicolumn{2}{c}{ Rata-rata } & \multicolumn{2}{c}{ Interpretasi } \\
& $\begin{array}{c}\text { Guru } \\
(\%)\end{array}$ & $\begin{array}{c}\text { Siswa } \\
(\%)\end{array}$ & $\begin{array}{c}\text { Guru } \\
(\%)\end{array}$ & $\begin{array}{c}\text { Siswa } \\
(\%)\end{array}$ & $\begin{array}{c}\text { Guru } \\
(\%)\end{array}$ & $\begin{array}{c}\text { Siswa } \\
(\%)\end{array}$ & $\begin{array}{c}\text { Guru } \\
(\%)\end{array}$ & $\begin{array}{c}\text { Siswa } \\
(\%)\end{array}$ & Guru & Siswa \\
\hline Pendahuluan & 88.89 & 83.34 & 96.3 & 92.59 & 100 & 98.15 & 95.06 & 91.36 & Baik & Baik \\
Questions & 81.84 & 74.08 & 85.19 & 85.19 & 85.19 & 96.3 & 84.07 & 85.19 & Baik & Baik \\
Answers & 77.78 & 77.78 & 88.89 & 88.89 & 88.89 & 100 & 85.19 & 88.89 & Baik & Baik \\
$\begin{array}{c}\text { Selecting } \\
\text { Informations }\end{array}$ & 84.45 & 73.34 & 84.45 & 80 & 88.89 & 88.89 & 85.93 & 80.74 & Baik & Baik \\
Aplications & 81.48 & 74.08 & 83.34 & 75.93 & 87.04 & 87.04 & 83.95 & 79.02 & Baik & Baik \\
Penutup & 88.89 & 85.19 & 88.89 & 88.89 & 88.89 & 88.89 & 88.89 & 87.66 & Baik & Baik \\
Jumlah & 503.33 & 467.81 & 527.06 & 511.49 & 538.9 & 559.27 & 523.09 & 512.86 & & \\
Rata-rata & 83.83 & 77.97 & 87.84 & 85.25 & 89.82 & 93.21 & 87.18 & 85.48 & & \\
Interpretasi & Baik & Baik & Baik & Baik & Baik & Baik & Baik & Baik & & \\
\hline
\end{tabular}

\section{Keterampilan proses sains}

Peningkatan keterampilan proses sains siswa pada setiap indikator terlihat pada GAMBAR 1 berikut.

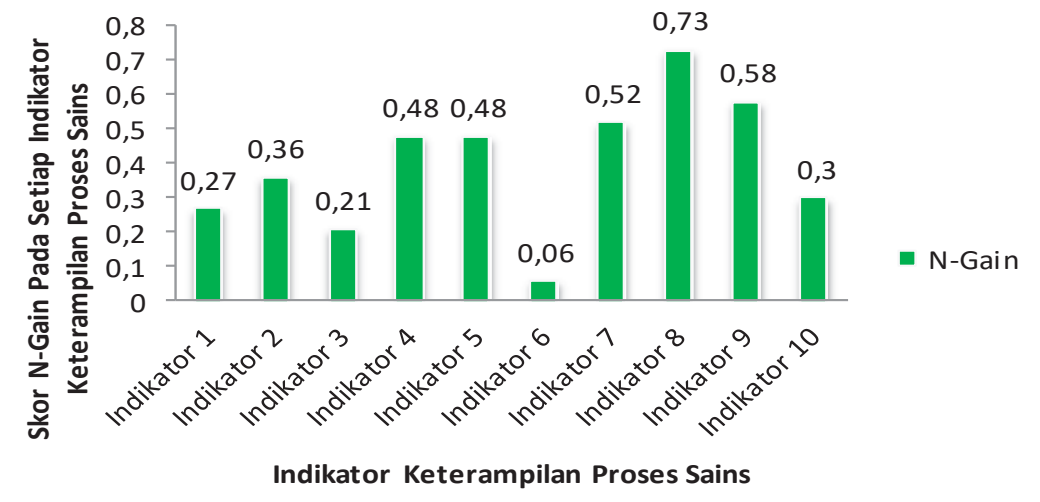

Keterangan: 1. kemampuan mengamati; 2. merencanakan percobaan; 3. membuat hipotesis; 4. menerapkan konsep; 5. menggunakan alat dan bahan; 6. mengkomunikasikan; 7. mengajukan pertanyaan; 8.menafsirkan; 9. mengklasifikasikan; 10. memprediksi.

GAMBAR 1. Peningkatan Penguasaan Keterampilan Proses Siswa pada setiap Indikator

Berdasarkan GAMBAR 1 peningkatan $\mathrm{N}$-gain KPS terendah terdapat pada indikator mengkomunikasikan sebesar 0,006 termasuk ke dalam interpretasi rendah. Indikator menafsirkan menunjukkan peningkatan N-gain KPS tertinggi sebesar 0,73 termasuk ke dalam interpretasi tinggi.

Rata-rata dari skor pretest, posttest dan $N$-Gain KPS pada setiap sub konsep ditunjukkan pada TABEL 2 berikut. Berdasarkan TABEL 2 peningkatan N-gain KPS terendah terdapat pada sub konsep keseimbangan benda tegar sebesar 0,47 termasuk ke dalam interpretasi sedang. Indikator sub konsep jenis-jenis keseimbangan menunjukkan peningkatan N-gain KPS tertinggi sebesar 0,70 termasuk ke dalam interpretasi tinggi.

Peningkatan keterampilan proses sains siswa pada materi keseimbangan benda tegar berdasarkan hasil pretest dan posttest sebesar 38,48 dengan rata-rata pretest dan posttest secara berturut-turut 
adalah 33,64 dan 72,12 . Nilai N-gain keterampilan proses sains siswa yang diperoleh sebesar 0,58 termasuk ke dalam interpretasi sedang.

TABEL 2. Skor Pretest, Posttest dan N-Gain KPS pada Setiap Sub Konsep

\begin{tabular}{|c|c|c|c|c|c|c|}
\hline \multirow[b]{2}{*}{ No } & \multirow[b]{2}{*}{ Sub Konsep } & \multirow[b]{2}{*}{ Nomor soal } & \multicolumn{4}{|c|}{ Rata-rata } \\
\hline & & & Pretest & Posttest & $N$-Gain & Interpretasi \\
\hline 1 & Keseimbangan benda tegar & $1,2,3,4$ & 30,3 & 60,61 & 0.47 & Sedang \\
\hline 2 & Titik berat & $5,6,7$ & 45,46 & 76,77 & 0,59 & Sedang \\
\hline 3 & Jenis-jenis keseimbangan & $8,9,10$ & 28,28 & 78,79 & 0,7 & Tinggi \\
\hline & Rata-rata & & 33,68 & 72,02 & 0,58 & Sedang \\
\hline
\end{tabular}

Berdasarkan uji normalitas nilai rata-rata pretest dan posttest menunjukkan berdistribusi tidak normal, dimana $X^{2}{ }_{\text {hitung }}>X_{\text {tabel }}^{2}, X^{2}$ hitung pada data pretest diperoleh hasil 10,81 dengan $X_{\text {tabel }}^{2} 7,81$, sedangkan pada data posttest untuk $X^{2}$ hitung diperoleh hasil 12,21 dengan $X^{2}$ tabel sebesar 7,81, sehingga dilakukan uji Wilcoxcon match pair. Berdasarkan hasil perhitungan dengan $\mathrm{n}=33$ didapatkan $Z_{\text {hitung }}=$ 5,70. Pada taraf signifikansi 0,05 besarnya nilai $Z_{\text {tabel }}=1,69$. Data tersebut menunjukkan bahwa nilai $Z_{\text {hitung }}$ lebih besar daripada nilai $Z_{\text {tabel }}(5,70>1,69)$. Dari analisis tersebut dapat disimpulkan bahwa terdapat peningkatan keterampilan proses sains siswa pada materi keseimbangan benda tegar setelah diterapkan model CBL.

\section{Pembahasan}

\section{Keterlaksanaan Model CBL}

Berdasarkan hasil analisis data skor rata-rata aktivitas guru dan siswa dalam pelaksanaan pembelajaran menggunakan model CBL termasuk kategori baik. Guru pada pertemuan pertama, kurang begitu maksimal dalam pembelajaran, karena guru belum mengenal dan mengetahui situasi dan kondisi kelas, serta guru dan siswa masih harus beradaptasi agar terjalin komunikasi yang baik. Guru pada pertemuan pertama menjelaskan dan mengarahkan siswa mengenai langkah pada model CBL. Siswa terlihat antusias memperhatikan penjelasan guru, sehingga mereka mulai dapat mengikuti setiap langkah model CBL dalam pembelajaran. Walaupun masih ada siswa yang masih merasa bingung dalam mengerjakan tugas pada setiap langkah yang diberikan oleh guru, tetapi mereka mengikutinya dengan cukup tertib.

Guru gada pertemuan kedua, sudah lebih dapat mengkondisikan kelas dan berkomunikasi dengan siswa. Siswa sudah mengetahui setiap langkah pada model CBL, sehingga guru dan siswa berperan aktif pada pembelajaran dan keseluruhan aktivitas guru dan siswa berjalan dengan baik. Pada pertemuan ketiga terlihat sekali terjadi peningkatan baik aktivitas guru maupun siswa. Siswa pada pertemuan ini sudah lebih berperan aktif lagi dalam pembelajaran. Antusiasme siswa terlihat pada setiap langkah model CBL, dimana persentase aktivitas siswa pada setiap langkah terkategori baik.

Model CBL merupakan model pembelajaran yang dapat membantu siswa membangun keterampilan dan menghubungkan konsep dengan fenomena dalam kehidupan sehari-hari serta membantu mempermudah proses belajar mengajar di kelas. Penerapan model CBL dapat dijadikan solusi untuk mengembangkan pembelajaran agar lebih bermakna, karena model CBL dimulai dari konteks dunia nyata dan memotivasi siswa untuk menggunakan pengetahuan awalnya, kemudian siswa belajar secara kelompok untuk mempelajari konsep secara mandiri (Seery, 2014: 1).

Model CBL memiliki empat langkah pembelajaran yaitu questions, answer, selecting informations dan aplications. Berdasarkan hasil analisis data yang diperoleh, untuk keterlaksanaan aktivitas guru terendah pada langkah aplications. Guru pada langkah aplications belum dapat mengkondisikan seluruh siswa ketika melakukan praktikum, sehingga masih ada siswa yang belum terlibat aktif dalam kegiatan praktikum. Keterlaksanaan aktivitas guru tertinggi pada langkah selecting informations, hal ini disebabkan karena guru dapat membuat siswa mengerti apa yang harus dikerjakannya dengan memberi penjelasan dan arahan untuk mengisi sejumlah pertanyaan yang 
disediakan dan mencari jawaban yang tepat dari berbagai sumber, sehingga siswa terlihat antusias dalam mengerjakan tugas.

Keterlaksanaan aktivitas siswa terendah pada langkah aplications, disebabkan karena siswa kurang memperhatikan penjelasan dan arahan guru, sehingga masih ada siswa yang kurang memahami petunjuk praktikum yang ada dalam Lembar Kegiatan Siswa (LKS). Keterlaksanaan aktivitas siswa tertinggi pada langkah answers, siswa pada langkah ini dituntut untuk mencari jawaban dari pertanyaan yang telah dibuatnya sendiri pada langkah questions sehingga mereka antusias dalam mencari jawaban dari pertanyaan yang dibuatnya sendiri. Hal ini sejalan dengan pendapat Edward (2012: 13) yang menyatakan model CBL merupakan suatu model yang dapat mengubah peran baik siswa maupun guru dimana siswa secara aktif terlibat dan berperan utama dalam pembelajaran sedangkan guru memfasilitasi siswa dalam membangun pengetahuan secara mandiri.

Kelebihan dari model CBL yaitu membantu siswa untuk meningkatkan keterampilan proses sains, melalui questions siswa mengajukan pertanyaan, sehingga mereka akan mengeluarkan apa yang ada dalam benaknya untuk dituliskan menjadi pertanyaan. Melalui answers siswa akan meningkatkan keterampilan proses sains memprediksi dengan cara memprediksi jawaban dari pertanyaan yang telah dibuat pada langkah sebelumnya. Melalui selecting informations siswa akan meningkatkan keterampilan proses sains mengkomunikasikan karena pada langkah ini siswa bekerja sama untuk mencari jawaban dari berbagai pertanyaan yang telah dibuat sehingga mereka berkomunikasi untuk menentukan jawabannya. Melalui applications siswa akan meningkatkan keterampilan proses sains merencanakan percobaan melalui kegiatan praktikum. Selain itu, model ini juga dapat membantu meningkatkan pengetahuan tentang aplikasi konsep dalam kehidupan sehari-hari melalui kegiatan membaca wacana pada langkah quetions. Hal ini selaras dengan pendapat Trimmer (2013: 3-6) yang menyatakan bahwa model CBL dapat membantu siswa menghubungkan fenomena dalam kehidupan sehari-hari dengan sebuah konsep, meningkatkan keterampilan proses sains, dapat membantu siswa kreatif dalam membentuk sebuah konsep secara mandiri, membantu siswa meningkatkan kesadaran bekerja secara kelompok untuk memecahkan masalah, membantu siswa meningkatkan kepercayaan diri ketika berdiskusi menyampaikan idenya dalam kerja kelompok dan dapat membantu siswa dalam membangun kemampuan dan kreativitas.

Salah satu kendala yang dialami ketika menerapkan model CBL ini adalah masalah waktu yang belum dapat dialokasikan dengan baik. Sebaiknya, sebelum memulai pembelajaran lebih baik diberikan penjelasan terlebih dahulu kepada siswa mengenai langkah-langkah model CBL. Dengan demikian siswa tidak banyak bertanya tentang apa yang akan dilakukannya selama pembelajaran. Hal ini yang akan membuat waktu yang sudah dialokasikan sebelumnya menjadi tidak sesuai dengan semestinya. Selain itu, kendala lain yang dialami yaitu sarana yang kurang memadai, karena di perpustakaan buku sumber yang dibutuhkan masih kurang. Sejalan dengan pendapat Putter-Smith (2013: 8) yang menyatakan bahwa tidak semua sekolah mungkin memiliki kesempatan untuk memenuhi persyaratan dan tuntutan untuk menerapkan model CBL, mengingat keterbatasan yang dimiliki setiap sekolah.

\section{Peningkatan Keterampilan Proses Sains}

Berdasarkan hasil analisis data skor rata-rata $\mathrm{N}$-gain keterampilan proses sains siswa termasuk kategori sedang. Dari sepuluh indikator keterampilan proses sains, indikator menafsirkan memperoleh $\mathrm{N}$-Gain tertinggi termasuk ke dalam interpretasi tinggi. Hal ini disebabkan karena selama pembelajaran, siswa dilatihkan untuk menafsirkan data hasil pengamatan untuk dibuat analisis dan simpulan. Sedangkan untuk indikator mengkomunikasikan memperoleh $N$-Gain terendah termasuk ke dalam interpretasi rendah. Hal ini disebabkan karena siswa kurang percaya diri dalam menyampaikan pendapat, masih harus dipaksa oleh guru dalam berdiskusi dan mempresentasikan hasil praktikum. Hal ini selaras dengan apa yang dinyatakan Seery (2014: 1) bahwa penerapan model CBL dapat dijadikan solusi untuk mengembangkan pembelajaran agar lebih bermakna, karena CBL dimulai dari konteks dunia nyata dan memotivasi siswa untuk menggunakan pengetahuan awalnya, kemudian siswa belajar secara kelompok untuk mempelajari konsep secara mandiri.

Dari ketiga sub konsep materi keseimbangan benda tegar, sub konsep jenis-jenis keseimbangan mendapatkan $\mathrm{N}$-Gain tertinggi termasuk ke dalam interpretasi tinggi. Hal tersebut disebabkan karena 
jenis-jenis keseimbangan mudah dipahami dan banyak ditemui siswa dalam kehidupan sehari-hari. Sedangkan untuk sub konsep keseimbangan benda tegar memperoleh $\mathrm{N}$-Gain terendah termasuk ke dalam interpretasi sedang. Hal ini disebabkan konsep keseimbangan benda tegar memiliki tingkat kesulitan yang tinggi dan jumlah soal yang lebih banyak dibanding konsep lainnya serta memerlukan perumusan matematis dalam penyelesaiannya.

Hasil pengujian hipotesis menunjukkan bahwa penerapan model CBL secara signifikan dapat meningkatkan keterampilan proses sains siswa. Kelebihan model CBL dalam meningkatkan keterampilan proses sains yaitu dalam pembelajarannya lebih berpusat pada siswa, guru berperan sebagai fasilitator, karena siswa yang lebih aktif dalam kegiatan belajar membangun konsep secara mandiri, menghubungkan konsep dan mengaplikasikannya dalam kehidupan sehari-hari serta bekerja sama dengan temannya untuk melakukan kegiatan praktikum. Hal ini sesuai dengan pendapat Tural (2013: 2) yang menyatakan bahwa model CBL terjadi hanya ketika siswa memproses informasi baru atau pengetahuan sedemikian rupa sehingga mereka dapat mengerti untuk membangun pengetahuannya sendiri (pemikiran mereka sendiri, pengalaman, dan respon). Model ini mengasumsikan pikiran secara alami, mencari makna dalam sebuah konteks yang berkaitan dengan lingkungan sekitarnya dengan mencari hubungan yang rasional dan terlihat manfaatnya.

Tawil dan Liliasari (2014: 11) menyatakan proses belajar mengajar dengan melibatkan siswa aktif dalam kegiatan pembelajaran dapat mengembangkan keterampilan proses sains siswa. Keterampilan proses sangat berperan dalam pengembangan konsep-konsep ilmiah. Sejalan dengan pernyataan Rustaman et al. (2004) yang menyatakan pendekatan keterampilan proses sains merupakan pendekatan pembelajaran yang berorientasi pada proses IPA. Hal ini diperkuat pernyataan Carey et al. dalam Hancer dan Yilmaz (2007) yang menyatakan bahwa keterampilan proses sains membantu membangun pengetahuan siswa.

\section{PENUTUP}

Hasil penelitian selama tiga kali pertemuan menerapkan model CBL pada materi keseimbangan benda tegar menunjukkan rata-rata keterlaksanaan aktivitas guru berkategori baik dengan persentase $87,00 \%$ dan rata-rata keterlaksanaan aktivitas siswa berkategori baik dengan persentase $85,22 \%$.

Terdapat peningkatan keterampilan proses sains siswa pada materi keseimbangan benda tegar setelah diterapkan model CBL dimana diperoleh rata-rata nilai $N$-Gain sebesar 0,58 termasuk ke dalam interpretasi sedang. Indikator keterampilan proses sains mengkomunikasikan memperoleh $\mathrm{N}$ Gain terendah $(0,06)$ dan $N$-Gain tertinggi $(0,73)$ pada indikator menafsirkan.

\section{UCAPAN TERIMA KASIH}

1. Terima kasih kepada Kepala Sekolah dan Guru Fisika di MAN Cisewu yang telah memberi izin sebagai tempat penelitian dan membantu selama penelitian.

2. Terima kasih kepada Ketua Prodi Pendidikan Fisika UIN Sunan Guning Djati Bandung yang telah membatu selama penelitian.

\section{REFERENSI}

Arroio, Agnaldo 2010, Context based learning: a role for cinema in science education (online). Tersedia:http://www.academia.edu/1598010/Context_based_learning_A_role_for_cinema_in_sci ence_education, Diunduh Kamis 11 Desember pukul 21.36 WIB.

Cheng, KK, et al 2004, Using online homework system enhances students learning of physics concepts in an introductory physics course, American Journal of Physics, vol. 72, no. 11, pp. 1447-1453.

Edward Rose, David 2012, Context Based Learning (online), Tersedia: http://www.springerlink.com/content/x25677874688873p/fulltext.html. Diunduh Kamis 18 Desember 2014 pukul 21.30 WIB. 
Fraenkel, JR \& Wallen, NE 2007, How to design and evaluate research in education, 6th edn, McGraw-Hill Book Co, New York.

Hancer \& Yilmaz 2007, The effects of characteristics of adolescence on the science process skills of the child, Journal of Applied Science, vol. 7, no. 23.

Ilka, Parchmann \& Luecken, Markus 2010, Context-based learning for students and teachers: professional development by participating in school innovation projects (online), Tersedia: https://www.sciencelearningcentres.org.uk/media/filer_public/7f/92/7f92688a-47f0-458f-a2b9-

649549f90db4/nslc_uyseg_seminar_parchmann. Diunduh Selasa 16 Desember 2014 pukul 16.47 WIB.

King, Donna T 2012, New perspectives on context-based chemistry education: using a dialectical sociocultural approach to view teaching and learning, Studies in Science Education, 48(1), pp. 5187 (online), Tersedia: http://eprints.qut.edu.au/48956/. Diunduh Selasa 16 Desember 2014 pukul 16.30 WIB.

Muthi, Fithriyani 2014, 'Penerapan model pembelajaran Context Based Learning (CBL) untuk mengembangkan keterampilan proses siswa pada materi garam terhidrolisis' Skripsi, Pendidikan Kimia UIN SGD Bandung, Tidak diterbitkan.

Putter, D., Smits. L.G.A., et al 2013, Mapping context-based learning environments: the contruction of an instrument (online), Tersedia: http://link.springer.com/article/10.1007/s10984-013-9143 9/fulltext.html, Diunduh Jum'at 12 Desember 2014 Pukul 20.15 WIB.

Rustaman, et al 2004, Strategi Belajar Mengajar Biologi, Jurusan Pendidikan Biologi, FPMIPA UPI, Bandung.

Sagala, Syaiful 2009, Konsep dan Makna Pembelajaran, Alfabeta, Bandung.

Seery, Michael 2014, Context Based Learning (online). Tersedia: http://www.rsc.org/blogs/eic/2014/07/context-based-learning-icce2014. Diunduh Senin 8 Desember 2014 pukul 20.12 WIB.

Semiawan, C 1987, Pendekatan Keterampilan Proses, Gramedia, Jakarta.

Tawil dan Liliasari 2014, Keterampilan-keterampilan Sains dan Implementasinya dalam Pembelajaran IPA, Badan Penerbit Universitas Negeri Makassar, Makassar.

Trimmer W et al 2013, Seeing the bigger picture through context based learning (online). Tersedia: http://akoaotearoa.ac.nz/download/file. Diunduh Rabu 17 Desember 2014 pukul 20.30 WIB.

Tural, Guner 2013, The Functioning of context-based physics instruction in higher education. Department of Secondary Science and Mathematics Education, Ondokuz Mays University (online). Tersedia: http://www.ied.edu.hk/apfslt/download/v14_issue1_files/tural. Diunduh Rabu 17 Desember 2014 pukul 20.10 WIB.

Wiana, Gina 2014, 'Penerapan model pembelajaran Context Based Learning untuk mengembangkan keterampilan generik sains siswa pada materi koloid' Skripsi, Pendidikan Kimia UIN Sunan Gunung Djati Bandung. Tidak diterbitkan. 